\title{
Mortality in community-dwelling elderly: coefficient and associated factors
}

\author{
Mortalidade em idosos comunitários: coeficiente e fatores associados \\ Mortalidad en la mayoría comunitaria: coeficiente y factores asociados
}

Sarah Caroline Oliveira de Souza Boitrago' ORCID: 0000-0001-8773-0628

Andressa Samantha Oliveira Souza' ORCID: 0000-0002-9662-4787

Pâmela de Oliveira Cunha' ORCID: 0000-0003-3987-3709

Maria Aparecida Vieira' ORCID: 0000-0002-7921-4049

Antônio Prates Caldeira' ORCID: 0000-0002-9990-9083

Jair Almeida Carneiro' ORCID: 0000-0002-9501-918X

Fernanda Marques da Costa' ORCID: 0000-0002-3008-7747

'Universidade Estadual de Montes Claros. Montes Claros, Minas Gerais, Brazil.

How to cite this article: Boitrago SCOS, Souza ASO, Cunha PO, Vieira MA, Caldeira AP, Carneiro JA, et al. Mortality in communitydwelling elderly: coefficient and associated factors. Rev Bras Enferm. 2021;74(Suppl 2):e20200612. https://doi.org/10.1590/0034-7167-2020-0612

\section{Corresponding author:}

Sarah Caroline Oliveira de Souza Boitrago E-mail: scosouza@hotmail.com

EDITOR IN CHIEF: Antonio José de Almeida Filho ASSOCIATE EDITOR: Ana Fátima Fernandes

\section{ABSTRACT}

Objective: Analyze the coefficient, associated factors, and causes of mortality in communitydwelling elderly. Method: Longitudinal and analytical study. Data collection, at baseline, was performed in the elderly's home. The first wave occurred after 42 months. Complementary data collection identified the cause of death. Variables analyzed: demographic, social, economic, and clinical. Logistic regression was used for data analysis. Results: The coefficient of mortality was $7.9 \%$. The variables associated with mortality were longevity, inability to read, absence of religious practice, stroke, consultation, and hospitalization in the last 12 months. The main groups of primary causes of death were ill-defined and unspecified causes of mortality, respiratory system diseases, and neoplasms. Conclusion: The coefficient of mortality in community-dwelling elderly was lower than national and international studies investigated. Descriptors: Mortality; Elderly; Public Health; Geriatric Nursing; Community Health Nursing.

\section{RESUMO}

Objetivo: Analisar o coeficiente, os fatores associados e as causas de mortalidade em idosos comunitários. Método: Estudo longitudinal e analítico. A coleta de dados, na linha de base, foi realizada no domicílio do idoso. A primeira onda ocorreu após 42 meses. Realizou-se coleta complementar para identificação da causa da morte. Variáveis analisadas: demográficas, sociais, econômicas e clínicas. Para análise dos dados, foi utilizada regressão logística. Resultados: O coeficiente de mortalidade foi 7,9\%. As variáveis associadas à mortalidade foram: longevidade, não saber ler, ausência de prática religiosa, acidente vascular encefálico, realização de consulta e internação nos últimos 12 meses. Os principais grupos de causas básicas de morte foram causas mal definidas e as não especificadas de mortalidade; doenças do aparelho respiratório; e neoplasias. Conclusão: $\mathrm{O}$ coeficiente de mortalidade em idosos comunitários mostrou-se menor em comparação aos estudos nacionais e internacionais investigados.

Descritores: Mortalidade; Idoso; Saúde Pública; Enfermagem Geriátrica; Enfermagem em Saúde Comunitária.

\section{RESUMEN}

Objetivo: Analizar el coeficiente, los factores relacionados y las causas de mortalidad en ancianos comunitarios. Método: Estudio longitudinal y analítico. La recogida de datos, en la línea de base, ha sido realizada en el domicilio del anciano. La primera onda ocurrió tras 42 meses. Realizó recogida complementar para identificación de la causa de la muerte. Variables analizadas: demográficas, sociales, económicas y clínicas. Para análisis de los datos, se utilizó regresión logística. Resultados: El coeficiente de mortalidad fue 7,9\%. Las variables relacionadas a la mortalidad fueron: longevidad, no saber leer, ausencia de práctica religiosa, accidente vascular encefálico, realización de consulta e internación en los últimos 12 meses. Los principales equipos de causas básicas de muerte fueron causas mal definidas y las no especificadas de mortalidad; enfermedades del aparato respiratorio; y neoplasias. Conclusión: El coeficiente de mortalidad en ancianos comunitarios se mostró menor en comparación a los estudios nacionales e internacionales investigados.

Descriptores: Mortalidad; Anciano; Salud Pública; Enfermería Geriátrica; Enfermería en Salud Comunitaria. 


\section{INTRODUCTION}

Aging is a worldwide phenomenon observed both in developed and developing countries. Due to Brazilss accelerated demographic transition in the last few years, we perceive the population's growing aging. Currently, $13 \%$ of the Brazilian population is composed of elderly people ${ }^{(1-3)}$.

The combination of demographic and epidemiological transitions is associated with the increase in the proportional mortality rate of the elderly in the general population and caused significant changes in the distribution of the leading causes of death among the elderly ${ }^{(4)}$. It is noteworthy that aging provides a more significant burden of chronic non-communicable diseases (NCDs) and disabilities and changes in the profile of illness and mortality of the population ${ }^{(5)}$.

In the context of elderly health, most studies are developed in hospitals or long-stay institutions ${ }^{(6-10)}$, where the characteristics of the population tend to be distinct and with profiles of greater frailty. Thus, there is a need for global assessment studies of the elderly, in the community's context, with longitudinal methodology and analysis of death's leading causes. The results can direct health services to develop better actions for the promotion and protection of this population's health ${ }^{(11-12)}$.

The aspects related to mortality are considered primary indicators for assessing the population's health by providing necessary information for developing public policies ${ }^{(12)}$. In this sense, identifying the conditions associated with mortality in community-dwelling elderly is essential so that strategies can be developed and applied in this population, aiming to provide quality to the additional years of life ${ }^{(4)}$.

\section{OBJECTIVE}

To analyze the coefficient, associated factors, and causes of mortality in community-dwelling elderly.

\section{METHODS}

\section{Ethical aspects}

All participants were informed about the research and agreed to sign the Informed Consent Form. The Research Ethics Committee of the Universidade de Montes Claros approved the research project.

\section{Design, period, and place of study}

A longitudinal and analytical study, with a quantitative, population-based approach, conducted with community-dwelling elderly in the urban area of Montes Claros, in the north of Minas Gerais, in the Southeast Region of Brazil. We followed the EQUATOR guidelines through the Strengthening the Reporting of Observational Studies in Epidemiology (STROBE).

Data collection at baseline took place between May and July 2013. The first wave of the study was conducted after an average period of 42 months, from November 2016 to February 2017. Between November 2018 and July 2019, the complementary collection was conducted at the Cartório de Registro Civil das Pessoas Naturais of the municipality of Montes Claros.

\section{Sample; criteria of inclusion and exclusion}

To calculate the sample size at baseline, we considered: the estimated population of 30,790 elderly residents in the urban region, according to data from the Instituto Brasileiro de Geografia e Estatística (IBGE, Brazilian Institute of Geography and Statistics) (3); a confidence level of $95 \%$; a conservative prevalence of $50 \%$; and a sampling error of $5 \%$.

Since this was a cluster sampling, the number identified was multiplied by a correction factor and design effect (deff) of 1.5\% and increased by $15 \%$ for possible losses. The minimum number of older adults defined by the sample calculation was $656^{(13)}$.

The sampling process was probabilistic, by conglomerates, and in two stages. In the first stage, the census sector was used as the sampling unit. In this stage, the neighborhoods, streets, and blocks were identified on maps of the city's urban area's census sectors. According to IBGE data, forty-two census sectors were randomly selected among the 362 urban sectors in the municipality ${ }^{(3)}$.

In the second stage, the number of households was defined according to the population density of individuals aged 60 years or older. In this stage, the sectors with the highest number of older people had more households allocated to them to produce a more representative sample. This study is part of a comprehensive analysis of the health conditions of the elderly in the municipality ${ }^{(13)}$.

The inclusion criteria adopted were being 60 years old or older and living in the allocated household. It was considered losses if the elderly were not available to participate in at least three visits on different days and times, even if previously scheduled.

\section{Study protocol}

Data collection was conducted in the residence of the elderly between May and July 2013. According to the Kappa agreement measure (0.8), the interviewers, previously trained and calibrated, walked through the census sectors from a previously defined point in each census sector to conduct the interviews. To define the household to be investigated, interviewers walked the randomly selected sector from its starting point to visit the households alternately. If there were older adults in the visited household, they were invited to participate in the study; otherwise, the next household was selected, following alternating households' criterion. If there was more than one older person in the household, the older one was selected ${ }^{(14)}$.

The first wave of the study was conducted after 42 months, from November 2016 to February 2017, to continue the investigation. The data collection instrument was supported by similar population-based studies ${ }^{(4,13)}$ and previously tested in a pilot study in a specially selected census sector, whose data were not included in the final work.

Between November 2018 and July 2019, the complementary collection to identify the cause of death of the elderly was carried out in the Cartório de Registro Civil de Pessoas Naturais of Montes Claros (Civil Registry Office of Natural Persons of Montes Claros). The data regarding the causes of death were present 
in the medical certificate for declaring the causes of death. We carried out groupings of the primary causes of death according to the chapters of the International Classification of Diseases (ICD), $10^{\text {th }}$ Revision ${ }^{(15)}$.

The dependent variable was mortality. For data analysis, the results of the dependent variable were dichotomized: mortality (yes or no).

The independent variables studied were demographic: gender (male or female); age group (up to 79 years or $\geq 80$ years); skin color (white or non-white). Social: marital status (with or without a partner); family arrangement (living alone or not living alone); education (more than four years of study or up to four years of study); literacy (inability to read or ability to read); religious practice (no or yes). Economic: own income (no or yes); monthly family income (more than one minimum wage or up to one minimum wage). Clinical: presence or absence of reported chronic diseases (hypertension, diabetes mellitus, heart disease, osteoarticular disease, osteoporosis, cancer, stroke, pulmonary embolism, chronic obstructive pulmonary disease, asthma); polypathology (no or yes); weight loss (no or yes); smoking (no or yes); self-perception of health (positive or negative), evaluated through the question: "How would you rate your health status? (a) rate your health status?"The response options were "very good,"'good," "regular," "bad," or "very bad." In the analysis of the data collected, the answers were dichotomized following similar studies on the subject assuming as positive perception of health the answers "very good," and "good," and negative perception of health the sum of the answers "regular," "bad," and "very bad"(16-17).

The depressive symptoms were verified employing the 15 questions of the Geriatric Depression Scale ${ }^{(18)}$. This instrument has already been validated nationally and is composed of negative/affirmative questions. A score of 6 or more points indicates depressive symptoms. Thus, the cutoff point adopted in this study was 5/6 (no/yes - equivalent to no case/case) ${ }^{(18-19)}$; the presence of caregiver (no or yes); fall in the last 12 months (no or yes); medical consultation in the last 12 months (no or yes); hospitalization in the last 12 months (no or yes); polypharmacy ( $<5$ or $\geq 5$ medications).

We applied the Edmonton Frailty Scale (EFS) to measure frailty, culturally adapted and validated for the Portuguese language ${ }^{(20)}$. It is an instrument that assesses nine domains: cognition, health status, functional independence, social support, medication use, nutrition, mood, urinary continence, and functional performance. The scale distributes the domains in 11 items with scores from 0 to 17. The EFS score can vary as follows: $0-4$, indicates no presence of frailty; 5-6, apparently vulnerable to frailty; 7-8, mild frailty; 9-10, moderate frailty; and 11 or more, severe frailty ${ }^{(21)}$. For data analysis in the present study, the variable results were dichotomized into two levels: not fragile (final score $\leq 6$ ) and fragile (score $>6$ ).

Limitations in Basic Activities of Daily Living (ADLs) and Instrumental Activities of Daily Living (IADLs) defined the functional disability. The ADLs were measured by the Katz Index, which establishes a score between 0 and 3 points. The elderly were completely independent for ADLs when he/she has a score of 0 ; with a score of 1 , the individual needs the help of some accessory (canes, bars, furniture support) to perform the activities; with 2 points, human help is essential to perform the tasks; and older people with 3 points are classified as entirely dependent ${ }^{(22)}$. The ADLs'limitations were assessed by the Lawton-Brody Scale, which is composed of more complex items in daily life. Based on the scale, the elderly are classified as independent for the IADLs when they obtain 27 points. Those with scores equal to or below 26 points are considered dependent ${ }^{(23)}$.

\section{Analysis results and statistics}

Initially, it was performed a descriptive analysis of the data. Bivariate analyses were performed to identify factors associated with the response variable using the chi-square test. The associations' magnitude was estimated using the odds ratio (OR). Logistic regression was used to calculate the adjusted OR, considering collectively the independent variables that were more strongly associated with mortality in the bivariate analysis, up to a significance level of $20 \%(p<0.20)$. For the final analysis, a significance level of $p<0.05$ was considered.

The collected information was analyzed using the Statistical Package for the Social Sciences (SPSS), version 17.0 (SPSS for Windows).

\section{RESULTS}

In the baseline of the study were allocated 685 communitydwelling elderly. There was a predominance of females (64.8\%), age group up to 79 years old (84.5\%), with a mean of 73.9 years old (SD \pm 7.9$)$, non-white skin color (68.6\%), who had a partner (51.4\%) and up to 4 years of education (76.2\%). Among the clinical characteristics, hypertension was the most commonly reported disease (70.9\%), followed by osteoarticular disease (35.2\%) and osteoporosis (25\%).

Among the 685 community-dwelling older adults evaluated at baseline, 92 refused to participate in the first wave of the study, 78 moved and could not be located, 67 were not found at home after three visits, and 54 died.

The study population's mortality rate was $7.9 \%$ after a mean period of 42 months. Among the elderly who had died in the first wave of the study, the majority were women (61.1\%), non-white skin color $(66.7 \%)$, without a partner $(57.4 \%)$, and had a religious practice $(63 \%)$. About the self-reported diseases, the most important were hypertension (70.4\%), heart disease (40.7\%), osteoarticular disease (37\%), osteoporosis (33.3\%), diabetes mellitus (29.6\%), and stroke (18.5\%). Most participants reported consultations in the last 12 months (98.1\%). Some were considered dependent for the IADLs (64.8\%) and had frailty (61.1\%). Table 1 shows the bivariate analysis of mortality according to demographic, social, and economic variables, while Table 2 demonstrates the bivariate analysis of mortality according to clinical variables.

The statistically significant variables were age, education, literacy, religious practice, heart disease, stroke, polypathology, weight loss, having a caregiver, falls, consultations and hospitalizations in the last 12 months, polypharmacy, frailty, basic and instrumental activities. These variables were inserted in the multiple analysis. The variables that, after multiple analyses, remained statistically associated with mortality in communitydwelling elderly were longevous elderly, unable to read, not having 
religious practice, having reported stroke, having consulted the doctor in the last year, and having been hospitalized in the last 12 months (Table 3).

The mortality of community-dwelling elderly according to the main groups of primary causes of death by ICD-10 is presented in Table 4. Besides the other ill-defined and unspecified causes of mortality $(44.4 \%)$, stand out respiratory system diseases (31.5\%) and neoplasms (9.3\%).

Table 1 - Bivariate analysis of mortality according to demographic, social and economic variables among community-dwelling elderly, using the Chi-square test, Montes Claros, Minas Gerais, Brazil, 2018 ( $N=685)$

\begin{tabular}{|c|c|c|c|c|c|c|c|}
\hline \multirow{3}{*}{$\begin{array}{l}\text { Independent } \\
\text { Variables }\end{array}$} & \multirow{2}{*}{\multicolumn{2}{|c|}{ Sample }} & \multicolumn{4}{|c|}{ Death } & \multirow{3}{*}{$\begin{array}{c}p \\
\text { value }\end{array}$} \\
\hline & & & \multicolumn{2}{|c|}{ Yes } & \multicolumn{2}{|c|}{ No } & \\
\hline & $\mathbf{n}$ & $\%$ & $\mathbf{n}$ & $\%$ & $\mathbf{n}$ & $\%$ & \\
\hline \multicolumn{8}{|l|}{ Demographic Characteristics } \\
\hline Gender & & & & & & & 0.552 \\
\hline Male & 241 & 35.2 & 21 & 8.7 & 220 & 91.3 & \\
\hline Female & 444 & 64.8 & 33 & 7.4 & 441 & 92.6 & \\
\hline Age group & & & & & & & $<0.001$ \\
\hline Up to 79 years old & 579 & 84.5 & 30 & 5.2 & 549 & 94.8 & \\
\hline$\geq 80$ years old & 106 & 15.5 & 24 & 22.6 & 82 & 77.4 & \\
\hline Skin color & & & & & & & 0.748 \\
\hline White & 215 & 31.4 & 18 & 8.4 & 197 & 91.6 & \\
\hline Non-white & 470 & 68.6 & 36 & 7.7 & 434 & 92.3 & \\
\hline \multicolumn{8}{|l|}{ Social Characteristics } \\
\hline Marital status & & & & & & & 0.178 \\
\hline With partner & 352 & 51.4 & 23 & 6.5 & 329 & 93.5 & \\
\hline Without partner & 333 & 48.6 & 31 & 9.3 & 302 & 90.7 & \\
\hline Family arrangement & & & & & & & 0.813 \\
\hline Living alone & 83 & 12.1 & 6 & 7.2 & 77 & 92.8 & \\
\hline Not living alone & 602 & 87.9 & 48 & 8.0 & 554 & 92.0 & \\
\hline Education & & & & & & & 0.023 \\
\hline$>4$ years & 163 & 23.8 & 6 & 3.7 & 157 & 157 & \\
\hline Up to 4 years & 522 & 76.2 & 48 & 9.2 & 474 & 90.8 & \\
\hline Literacy & & & & & & & $<0.001$ \\
\hline Ability to read & 489 & 71.4 & 27 & 5.5 & 462 & 94.5 & \\
\hline Inability to read & 196 & 28.6 & 27 & 13.8 & 169 & 86.2 & \\
\hline Religious practice & & & & & & & $<0.001$ \\
\hline Yes & 561 & 81.9 & 34 & 6.1 & 527 & 93.9 & \\
\hline No & 124 & 18.1 & 20 & 16.1 & 104 & 83.9 & \\
\hline \multicolumn{8}{|l|}{ Economic Characteristics } \\
\hline Own income & & & & & & & 0.072 \\
\hline Yes & 609 & 88.9 & 52 & 8.5 & 557 & 91.5 & \\
\hline No & 76 & 11.1 & 2 & 2.6 & 74 & 97.4 & \\
\hline Monthly Family income & & & & & & & 0.266 \\
\hline$>1$ salary* & 489 & 71.4 & 35 & 7.2 & 454 & 92.8 & \\
\hline Up to 1 salary & 196 & 28.6 & 19 & 9.7 & 177 & 90.3 & \\
\hline
\end{tabular}

Table 2 - Bivariate analysis of mortality according to clinical variables among community-dwelling elderly, using Chi-square test, Montes Claros, Minas Gerais, Brazil, $2018(N=685)$

\begin{tabular}{|c|c|c|c|c|c|c|c|}
\hline \multirow{3}{*}{$\begin{array}{l}\text { Independent } \\
\text { Variables }\end{array}$} & \multirow{2}{*}{\multicolumn{2}{|c|}{ Sample }} & \multicolumn{4}{|c|}{ Death } & \multirow{3}{*}{$\begin{array}{c}p \\
\text { value }\end{array}$} \\
\hline & & & & es & & lo & \\
\hline & 11 & $\%$ & $n$ & $\%$ & $n$ & & \\
\hline \multicolumn{8}{|c|}{ Clinical Characteristics } \\
\hline Hypertension & & & & & & & 0.922 \\
\hline Yes & 486 & 70.9 & 38 & 7.8 & 448 & 92.2 & \\
\hline Noo & 199 & 29.1 & 16 & 8.0 & 183 & 92.0 & \\
\hline Diabetes Mellitus & & & & & & & 0.180 \\
\hline Yes & 153 & 22.3 & 16 & 10.5 & 137 & 89.5 & \\
\hline No & 532 & 77.7 & 38 & 7.1 & 494 & 92.9 & \\
\hline
\end{tabular}

Table 2 (concluded)

\begin{tabular}{|c|c|c|c|c|c|c|c|}
\hline \multirow{3}{*}{$\begin{array}{l}\text { Independent } \\
\text { Variables }\end{array}$} & \multirow{2}{*}{\multicolumn{2}{|c|}{ Sample }} & \multicolumn{4}{|c|}{ Death } & \multirow{3}{*}{$\begin{array}{c}p \\
\text { value }\end{array}$} \\
\hline & & & \multicolumn{2}{|c|}{ Yes } & \multicolumn{2}{|c|}{ No } & \\
\hline & $\mathbf{n}$ & $\%$ & $\mathbf{n}$ & $\%$ & $\mathbf{n}$ & $\%$ & \\
\hline Heart Disease & & & & & & & 0.003 \\
\hline Yes & 164 & 23.9 & 22 & 13.4 & 142 & 86.6 & \\
\hline No & 521 & 76.1 & 32 & 6.1 & 489 & 93.9 & \\
\hline Osteoarticular disease & & & & & & & 0.766 \\
\hline Yes & 241 & 35.2 & 20 & 8.3 & 221 & 91.7 & \\
\hline No & 444 & 64.8 & 34 & 7.7 & 410 & 92.3 & \\
\hline Osteoporosis & & & & & & & 0.139 \\
\hline Yes & 171 & 25.0 & 18 & 10.5 & 153 & 89.5 & \\
\hline No & 514 & 75.0 & 36 & 7.0 & 478 & 93.0 & \\
\hline Neoplasm & & & & & & & 0.831 \\
\hline Yes & 22 & 3.2 & 2 & 9.1 & 20 & 90.9 & \\
\hline No & 663 & 96.8 & 52 & 7.8 & 611 & 92.2 & \\
\hline Stroke & & & & & & & \\
\hline Yes & 38 & 5.5 & 10 & 26.3 & 28 & 73.7 & \\
\hline No & 647 & 94.5 & 44 & 6.8 & 603 & 93.2 & \\
\hline Pulmonary embolism & & & & & & & 0.071 \\
\hline Yes & 8 & 1.2 & 2 & 25.0 & 6 & 75.0 & \\
\hline No & 677 & 98.8 & 52 & 7.7 & 625 & 92.3 & \\
\hline $\begin{array}{l}\text { Chronic obstructive } \\
\text { pulmonary disease }\end{array}$ & & & & & & & \\
\hline Yes & 30 & 4.4 & 3 & 10.0 & 27 & 90.0 & \\
\hline No & 655 & 95.6 & 51 & 7.8 & 604 & 92.2 & \\
\hline Asthma & & & & & & & 0.497 \\
\hline Yes & 37 & 5.4 & 4 & 10.8 & 33 & 89.2 & \\
\hline No & 648 & 94.6 & 50 & 7.7 & 598 & 92.3 & \\
\hline Polypathology & & & & & & & 0.001 \\
\hline Yes & 7 & 1.0 & 3 & 42.9 & 4 & 57.1 & \\
\hline No & 678 & 99.0 & 51 & 7.5 & 627 & 92.5 & \\
\hline Self-perception of health & & & & & & & 0.119 \\
\hline Positive & 593 & 86.6 & 43 & 7.3 & 550 & 92.7 & \\
\hline Negative & 92 & 13.4 & 11 & 12.0 & 81 & 88.0 & \\
\hline Weight loss & & & & & & & 0.018 \\
\hline Yes & 253 & 36.9 & 28 & 11.1 & 225 & 88.9 & \\
\hline No & 432 & 63.1 & 26 & 6.0 & 406 & 94.0 & \\
\hline Smoking & & & & & & & 0.956 \\
\hline Yes & 302 & 44.1 & 24 & 7.9 & 278 & 92.1 & \\
\hline No & 383 & 55.9 & 30 & 7.8 & 353 & 92.2 & \\
\hline Depression & & & & & & & 0.486 \\
\hline Yes & 200 & 29.2 & 18 & 9.0 & 182 & 91.0 & \\
\hline No & 485 & 70.8 & 36 & 7.4 & 449 & 92.6 & \\
\hline Has a caregiver & & & & & & & $<0.001$ \\
\hline Yes & 117 & 17.1 & 22 & 18.8 & 95 & 81.2 & \\
\hline No & 568 & 82.9 & 32 & 5.6 & 536 & 94.4 & \\
\hline Fall in the last 12 months & & & & & & & 0.035 \\
\hline Yes & 194 & 28.3 & 22 & 11.3 & 172 & 88.7 & \\
\hline No & 491 & 71.7 & 32 & 6.5 & 459 & 93.5 & \\
\hline $\begin{array}{l}\text { Consultation in the last } \\
12 \text { months }\end{array}$ & & & & & & & 0.036 \\
\hline Yes & 616 & 89.9 & 53 & 8.6 & 563 & 91.4 & \\
\hline No & 69 & 10.1 & 1 & 1.4 & 68 & 98.6 & \\
\hline $\begin{array}{l}\text { Hospitalization in the } \\
\text { last } 12 \text { months }\end{array}$ & & & & & & & $<0.001$ \\
\hline Yes & 121 & 17.7 & 21 & 17.4 & 100 & 82.6 & \\
\hline No & 564 & 82.3 & 33 & 5.9 & 531 & 94.1 & \\
\hline Polypharmacy & & & & & & & 0.002 \\
\hline$\geq 5$ Medications & 161 & 23.5 & 22 & 13.7 & 139 & 86.3 & \\
\hline$<5$ Medications & 524 & 76.5 & 32 & 6.1 & 492 & 93.9 & \\
\hline Frailty & & & & & & & $<0.001$ \\
\hline Frail & 243 & 35.5 & 33 & 13.6 & 210 & 86.4 & \\
\hline Not frail & 442 & 64.5 & 21 & 4.8 & 421 & 95.2 & \\
\hline Basic Activities & & & & & & & $<0.001$ \\
\hline Dependent & 62 & 9.1 & 13 & 21.0 & 49 & 79.0 & \\
\hline Independent & 623 & 90.9 & 41 & 6.6 & 582 & 93.4 & \\
\hline Instrumental Activities & & & & & & & 0.001 \\
\hline Dependent & 296 & 43.2 & 35 & 11.8 & 261 & 88.2 & \\
\hline Independent & 389 & 56.8 & 19 & 4.9 & 370 & 95.1 & \\
\hline
\end{tabular}


Table 3 - Factors associated with mortality among community-dwelling elderly in Montes Claros, Minas Gerais, Brazil, 2018

\begin{tabular}{lccc}
\hline Variable & $\begin{array}{c}\text { OR } \\
\text { (adjusted) }\end{array}$ & Cl (95\%) & $\begin{array}{c}\boldsymbol{p} \\
\text { value }\end{array}$ \\
\hline $\begin{array}{l}\text { Age } \\
\quad \text { Up to 79 years old } \\
\quad \text { 80 years old }\end{array}$ & 1 & & \\
$\begin{array}{l}\text { Literacy } \\
\quad \text { Ability to read } \\
\quad \text { Inability to read }\end{array}$ & 4.12 & $2.18-7.79$ & $<\mathbf{0 . 0 0 1}$ \\
$\begin{array}{l}\text { Religious Practice } \\
\text { Yes }\end{array}$ & 1 & & \\
$\quad$ No & 2.25 & $1.21-4.19$ & 0.010 \\
$\begin{array}{l}\text { Stroke } \\
\quad \text { No }\end{array}$ & 1 & & \\
$\quad$ Yes & 2.38 & $1.23-4.60$ & 0.010 \\
$\begin{array}{l}\text { Consultation in the last 12 months } \\
\quad \text { No }\end{array}$ & 1 & & \\
$\quad$ Yes & 4.10 & $1.71-9.83$ & 0.002 \\
$\begin{array}{l}\text { Hospitalizations in the last 12 months } \\
\quad \text { No }\end{array}$ & 1 & $1.06-68.45$ & $<\mathbf{0 . 0 0 1}$ \\
$\quad$ Yes & 8.51 & & \\
\hline
\end{tabular}

Table 4 - Mortality according to the main groups of primary causes of death by ICD-10 among community elderly, Montes Claros, Minas Gerais, Brazil. $2018(n=54)$

\begin{tabular}{lcc}
\hline \multirow{2}{*}{ Groups of causes } & \multicolumn{2}{c}{ Sample } \\
& n & \% \\
\hline Diseases of the circulatory system & 4 & 7.4 \\
Diseases of the digestive tract & 3 & 5.5 \\
Diseases of the respiratory system & 17 & 31.5 \\
External causes of mortality & 1 & 1.9 \\
Neoplasms & 5 & 9.3 \\
Other ill-defined and unspecified causes of mortality & 24 & 44.4 \\
Total & 54 & 100 \\
\hline
\end{tabular}

\section{DISCUSSION}

This study identified a coefficient of mortality of $7.9 \%$ in community-dwelling elderly individuals during an average period of 42 months. Brazilian studies have identified different coefficients of mortality in the elderly during different follow-up periods: $8.9 \%$ during five years of follow-up ${ }^{(4)} ; 17.8 \%$ at 8.4 years of follow-up ${ }^{(24)}$; and $15.7 \%$ at 4.06 years of follow-up ${ }^{(25)}$. International investigations have pointed out a high coefficient of mortality in the elderly. In China, research showed a coefficient of mortality of $36.3 \%$ and $46.1 \%$ during 2.8 years and six years of follow-up, respectively ${ }^{(26-27)}$. In Japan, the coefficient was $21.6 \%$ during a 9-year follow-up ${ }^{(28)}$.

Differences in the studies' follow-up period justify the disparities found in the coefficient of mortality in the elderly, besides the variation in the mean age of the elderly since the studies with high mean age showed higher mortality rates ${ }^{(5)}$.

Mortality was associated with greater longevity. A study conducted with community-dwelling elderly in Ribeirão Preto, São Paulo, showed that older adults above 80 years were 2.3 times more likely to die than those in the youngest age group ${ }^{(29)}$. In Ireland, a survey with older adults receiving state-funded home support $(n=1,597)$ identified one of the main determinants of mortality in advanced age ${ }^{(30)}$.
The variable "inability to read" was also associated with mortality. Studies investigated the variable "education" ${ }^{\text {"27,29) }}$ and found no association with mortality. However, the SABE study found out that the higher the survival of the elderly, the higher the level of education ${ }^{(31)}$. Hence, we inferred that, since education is a determining and conditioning factor of health, low education can compromise the health self-care of the elderly ${ }^{(32)}$. Moreover, individuals with high education levels may have better access to advantages and health services that ensure their quality of life and good health status ${ }^{(33)}$. An alternative to face the low education of the elderly would be implementing health literacy in Primary Health Care. This concept is related to the individual's ability to understand the information and services needed to make appropriate health decisions. For the elderly, who generally have multimorbidity and often use the health care system, adequate health literacy can help them better access this system and obtain positive health outcomes ${ }^{(34)}$. Therefore, studies are needed to evaluate the association between health literacy in the elderly population and its relationship with mortality in community-dwelling elderly.

The absence of religious practice was associated with mortality. Studies that addressed factors associated with mortality in community-dwelling elderly ${ }^{(4,24,26,29)}$ did not investigate the variable "religious practice." A longitudinal survey on religiosity and longevity conducted in Taiwan with older adults $(n=3,849)$, over 18 years of follow-up, showed, using a Gompertz regression, adjusted and unadjusted for covariates and mediating factors, that the risk of dying is lower for the religiously active compared with the non-religious, with a 60-year-old religiously active Taiwanese woman living one year longer than her non-religious counterpart ${ }^{(35)}$. Religiosity and the search for the divine may be related to individuals' social, physical, mental, and spiritual well-being, leading to better coping with adverse conditions(36). Practices that involve religion and spirituality can contribute to face uncertainties, challenges, losses, and stressful events in life $\mathrm{e}^{(37)}$. So, it is necessary to conduct studies addressing religious coping in the older population and its relationship with mortality.

Generally, we expect high mortality rates among older people who have suffered a stroke. There was a significant association between this clinical condition and mortality in the present study. In this sense, Brazilian research conducted with community-dwelling elderly individuals observed higher odds ratios for mortality in the presence of heart disease $(\mathrm{OR}=1.76 ; 95 \% \mathrm{Cl} 0.98-3.14)^{(4)}$. Furthermore, ecological studies conducted in the Rio Grande do Norte ${ }^{(5)}$ and Acre ${ }^{(12)}$ identified that the leading cause of death in older adults is the circulatory system's diseases, being even more evident among the longevous adults. The most frequent specific cause is stroke. These changes are related to the aging process, in which there is a more significant presence of chronic diseases, frailty, and functional loss ${ }^{(38)}$.

The results showed an association between mortality and the elderly having consultations and hospitalizations in the last 12 months. Such variables were not investigated in studies ${ }^{(4,24,26,29)}$ of mortality among community-dwelling elderly. However, a national household survey conducted with older people $(\mathrm{n}=$ 23,815 ) pointed out that medical consultations and hospitalizations have significant associations with functional limitation of 
older adults ${ }^{(39)}$, one of the characteristics present in the frailty syndrome. Thus, the elderly who seek medical and hospital care frequently may have a more significant functional impairment, which generates disabilities and risk of adverse outcomes.

Considering the fragility issue, studies ${ }^{(29,40)}$ evidenced the association between this factor and mortality, which did not appear in this study. A Brazilian study conducted with community-dwelling elderly individuals in a 66-month follow-up identified that frailty increased during the follow-up period and was associated with mortality ${ }^{(29)}$. Also, in a systematic review with a meta-analysis of prospective studies with community-dwelling elderly, it was shown that the older people with frailty presented the highest mortality risks ${ }^{(41)}$. In a population-based cohort study conducted in Spain with individuals over 70 years of age, frail participants had an increased adjusted risk of death (HR 4.5, 95\% Cl: 1.8-11.1)

${ }^{(40)}$. Finally, frailty comprises older adults' biological, psychological, social, and cognitive factors that may affect life quality, leading to hospitalization, institutionalization, and death ${ }^{(42)}$.

The most frequent groups of underlying causes of death by ICD-10 among the community-dwelling elderly investigated were other ill-defined and unspecified causes of mortality and respiratory system diseases. In accordance with the findings, a study conducted in Fortaleza to analyze the quality of information on deaths from external causes identified the inadequate filling out of death certificates and inconsistencies in establishing death's underlying cause. Such factors contribute to the fragility of the Mortality Information System (SIM) and difficulty in identifying and codifying the cause of death ${ }^{(43)}$. Therefore, there is a need to train professionals responsible for adequately completing such documents.

Moreover, an ecological study conducted in the Rio Grande do Norte to analyze the mortality profile of the elderly population identified that ill-defined causes and respiratory system diseases are the second and third cause of death, respectively, for older adults. That reflects the difficulty of characterizing individuals' death in people over 80 years old and the precariousness of the information for determining the primary cause of death ${ }^{(5)}$.

\section{Study limitations}

This study's results should be interpreted according to the understanding of some limitations. Studies have shown that childhood living conditions ${ }^{(31)}$, cognitive decline ${ }^{(26)}$, body composition $^{(25)}$, and biomarkers of oxidative stress ${ }^{(27)}$ are associated with mortality in older people. These conditions were not investigated in the present study. Between investigations at baseline and in the first wave of the study, there was a loss of participants who moved away or could not be found at home. In addition, some instrument components were self-reported, which depends on the memory of the older person or caregiver interviewed. Even with limitations, it is noteworthy that the study has a representative random sample of community-dwelling elderly, and the instruments used are validated and reliable.

\section{Contributions to the Fields of Nursing, Health or Public Policy}

Knowledge about older people's mortality may subsidize public policies in the health field since identifying risk factors and the leading causes of death in community-dwelling elderly allow acting on the modifiable conditions. Thus, actions can be established to prevent diseases and health promotion to add quality to the additional years of life, a fundamental role of healthcare professionals and services.

\section{CONCLUSION}

The coefficient of mortality in community-dwelling elderly in this study was lower than the national and international studies investigated. However, it should be considered that the followup periods between the studies were different. The conditions linked with mortality found a significant association with the following variables: longevity, inability to read, absence of religious practice, stroke, consultation, and hospitalization in the last 12 months. The main groups of primary causes of death by ICD-10 were respiratory system diseases and neoplasms, other ill-defined causes, and unspecified causes of mortality.

\section{REFERENCES}

1. Leite AKF, Ribeiro KB. Older adults with cancer in the city of São Paulo: what factors determine the place of death? Rev Saúde Pública. 2018;52(66):1-7. https://doi.org/10.11606/S1518-8787.2018052016410

2. Telarolli JR, Loffredo LCM. [Mortality of the elderly in a municipality of southeastern Brazil from 2006 to 2011 ]. Ciênc Saúde Coletiva. 2014;19(3):975-84. https://doi.org/10.1590/1413-81232014193.10482012 Portuguese. 
3. Instituto Brasileiro e Geografia e Estatística (IBGE). Cidades@. Brasil. Minas Gerais. Montes Claros. [Internet] Rio de Janeiro: IBGE; 2010[cited 2019 Oct 04]. Available from: https://cidades.ibge.gov.br/brasil/mg/montes-claros/pano-rama.

4. Borim FSA, Francisco PMSB, Neri AL. Sociodemographic and health factors associated with mortality in community-dwelling elderly. Rev Saúde Pública. 2017;51(42):1-12. https://doi.org/10.1590/s1518-8787.2017051006708

5. Oliveira TC, Medeiros WR, Lima KC. [Mortality differentials by cause in extreme age groups of elderly]. Rev Bras Geriatr Gerontol. 2015;18(1):85-94. https://doi.org/10.1590/1809-9823.2015.14203 Portuguese.

6. Abreu DROM, Novaes ES, Oliveira RR, Mathias TAF, Marcon SS. Fall-related admission and mortality in older adults in Brazil: trend analysis. Ciênc Saúde Coletiva. 2018;23(4):1131-41. https://doi.org/10.1590/1413-81232018234.09962016

7. Cordeiro P, Martins M. Hospital mortality in older patients in the Brazilian Unified Health System, Southeast region. Rev Saúde Pública. 2018;52(69):1-13. https://doi.org/10.11606/s1518-8787.2018052000146

8. Bonfada D, Santos MM, Lima KC, Garcia-Altés A. Survival analysis of elderly patients in Intensive Care Units. Rev Bras Geriatr Gerontol. 2017;20(2):198-206. https://doi.org/doi.org/10.1590/1981-22562017020.160131

9. Santos VC, Anjos KF, Boery RNSO, Moreira RM, Cruz DP, Boery EN. Hospitalization and hospital mortality of elderly people with mental and behavioral disorders in Brazil, 2008-2014. Epidemiol Serv Saúde. 2017;26(1):39-49. https://doi.org/doi.org/10.5123/ s1679-49742017000100005

10. Cascão AM, Jorge MHPM, Costa AJL, Kale PL. Use of primary diagnosis during hospitalization in the Unified Health System (Sistema Único de Saúde) to qualify information regarding the underlying cause of natural deaths among the elderly. Rev Bras Epidemiol. 2016;19(4):713-26. https://doi.org/10.1590/1980-5497201600040003

11. Cabral JF, Silva AMC, Mattos IE, Neves AQ, Luz LL, Ferreira DB, et al. Vulnerability and associated factors among older people using the Family Health Strategy. Ciênc Saúde Coletiva. 2019;24(9):3227-36. https://doi.org/10.1590/1413-81232018249.22962017

12. Bezerra PCL, Monteiro GTR. Trends in overall mortality and from diseases of the circulatory system in elderly individuals in Rio Branco, Acre, 1980-2012. Rev Bras Geriatr Gerontol. 2018;21(2):145-57. https://doi.org/10.1590/1981-22562018021.170128

13. Carneiro JA, Ramos GCF, Barbosa ATF, Mendonça JMG, Costa FM, Caldeira AP. Pevalence and factors associated with frailty in noninstitutionalized older adults. Rev Bras Enferm. 2016;69(3):435-42. https://doi.org/10.1590/0034-7167.2016690304i

14. Carneiro JA, Ramos GCF, Barbosa ATF, Medeiros SM, Lima CA, Costa FM, et al. Prevalence and factors associated to urinary incontinence in non-institutionalized elderly. Cad Saúde Coletiva. 2017;25(3):268-77. https://doi.org/10.1590/1414-462X201700030295

15. Organização Mundial da Saúde (OMS). CID-10 Classificação Estatística Internacional de Doenças e Problemas Relacionados à Saúde. 10a rev. São Paulo: Universidade de São Paulo: 1997. vol.1.

16. Aguilar-Palacio I, Carrera-Lasfuentes P, Rabanaque MJ. [Self-rated health and educational level in Spain: Trends by autonomous communities and gender (2001-2012)]. Gac Sanit. 2015;29(1):37-43. https://doi.org/10.1016/j.gaceta.2014.07.004 Spanish.

17. Ocampo-Chaparro JM, Zapata-Ossa HJ, Cubides-Munévar AM, Curcio CL, Villegas JD, Reyes-Ortiz CA. Prevalence of poor self-rated health and associated risk factors among older adults in Cali, Colombia. Colomb Med[Internet]. 2013 [cited 2019 Oct 04];44(4):224-31. Available from: http://www.scielo.org.co/pdf/cm/v44n4/v44n4a05.pdf

18. Almeida OP, Almeida SA. [Reliability of the Brazilian version of the Geriatric Depression Scale (GDS) reduced version]. Arq Neuropsiquiatr. 1999;57(2B):421-26. https://doi.org/10.1590/S0004-282X1999000300013 Portuguese.

19. Ferrari JF, Dalacorte RR. Uso da Escala de Depressão Geriátrica de Yesavage para avaliar a prevalência de depressão em idosos hospitalizados. Sci Med [Internet]. 2007 [cited 2019 Oct 04];17(1):3-8. Available from: http://revistaseletronicas.pucrs.br/ojs/index.php/ scientiamedica/article/view/1597/1837

20. Fabrício-Wehbe SCC, Schiaveto FV, Vendrusculo TRP, Haas VJ, Dantas RAS, Rodrigues RAP. Cross-cultural adaptation and validity of the "Edmonton Frail Scale - EFS" in a Brazilian elderly sample. Rev Latino-Am Enfermagem. 2009;17(6):1043-9. https://doi.org/10.1590/ S0104-11692009000600018

21. Rolfson DB, Majumdar SR, Tsuyuki RT, Tahir A, Rockwood K. Validity and reliability of the Edmonton Frail Scale. Age Ageing. 2006;35(1):526-9. https://doi.org/10.1093/ageing/afl041

22. Katz S, Ford AB, Moskowitz RW, Jackson BA, Jaffe MW. Studies of illness in the aged. The index of ADL: a standardized measure of biological and psychosocial function. JAMA. 1963;185(12):914-9. https://doi.org/10.1001/jama.1963.03060120024016

23. Lawton MP, Brody EM. Assessment of older people: self-maintaining and instrumental activities of daily living. Gerontol [Internet]. 1969 [cited 2019 Oct 04];9(3):179-86. Available from: http://www.eurohex.eu/bibliography/pdf/Lawton_Gerontol_19691502121986/Lawton_Gerontol_1969.pdf

24. Soares VN, Fattori A, Neri AL, Fernandes PT. Influence of physical performance on elderly mortality, functionality and life satisfaction: FIBRA's study data. Ciênc Saúde Coletiva. 2019;24(11):4181-90. https://doi.org/10.1590/1413-812320182411.07592018

25. Santana FM, Domiciano DM, Gonçalves MA, Machado, LG, Figueiredo CP, Lopes JB, et al. Association of appendicular lean mass, and subcutaneous and visceral adipose tissue with mortality in older Brazilians: the São Paulo ageing e health study. J Bone Miner Res. 2019;34(7):1264-74. https://doi.org/10.1002/jbmr.3710

26. Lv X, Li W, Ma Y, Chen H, Zeng Y, Yu X, et al. Cognitive decline and mortality among community-dwelling Chinese older people. BMC Med. 2019;17(63):1-10. https://doi.org/doi.org/10.1186/s12916-019-1295-8 
27. Mao C, Yuan JQ, Lv YB, Gao X, Yin ZX, Kraus VB, et al. Associations between superoxide dismutase, malondialdehyde and all-cause mortality in older adults: a community based cohort study. BMC Geriatr. 2019;19(104):1-9. https://doi.org/doi.org/10.1186/s12877-019-1109-z

28. Kitamura A, Taniguchi Y, Seino S, Yokoyama Y, Amano H, Fujiwara Y, et al. Combined effect of diabetes and frailty on mortality and incident disability in older Japanese adults. Geriatr Gerontol Int. 2019;19(5):428-8. https://doi.org/doi.org/10.1111/ggi.13637

29. Diniz MA, Rodrigues RAP, Fhon JRS, Haas VJ, Fabrício-Wehbe SCC, Giacomini SBL, et al. Frailty and its relationship to mortality among older adults from a Brazilian community: a cohort study. J Clin Gerontol Geriatr. 2018;9(1):27-33. https://doi.org/10.24816/jcgg.2018.v9i1.06

30. Aspell N, O'sullivan M, O'shea E, Irving K, Duffy C, Gorman R, et al. Predicting admission to long-term care and mortality among communitybased, dependent older people in Ireland. Int J Geriatr Psychiatr. 2019;34(7):999-1007. https://doi.org/10.1002/gps.5101

31. Gomes MMF, Turra CM, Fígoli MGB, Duarte YAO, Lebrão ML. Past and present: conditions of life during childhood and mortality of older adults. Rev Saúde Pública. 2015;49(93):1-11. https://doi.org/10.1590/S0034-8910.2015049005555

32. Borba AKOT, Arruda IKG, Marques APO, Leal MCC, Diniz AS. Knowledge and attitude about diabetes self-care of older adults in primary health care. Ciênc Saúde Coletiva. 2019;24(1):125-36. https://doi.org/10.1590/1413-81232018241.35052016

33. Belém PLO, Melo RLP, Pedraza DF, Menezes TN. Self-assessment of health status and associated factors in elderly persons registered with the Family Health Strategy of Campina Grande, Paraíba. Rev Bras Geriatr Gerontol. 2016;19(2):265-76. https://doi. org/10.1590/1809-98232016019.140206

34. Maduka DO, Swanson MR, Markey K, Anderson BJ, Tracy M, Manganello JA. Health literacy among in-care older HIV diagnosed persons with multimorbidity: MMP NYS (Excluding NYC). AIDS Behav. 2019;24(1):1092-105. https://doi.org/10.1007/s10461-019-02627-0

35. Zimmer Z, Chiu CT, Saito Y, Lin YH, Ofstedal MB, Jagger C. Does religious activity distinguish the mortality experiences of older Taiwanese? analysis using eighteen years of follow-up data. J Relig Health. 2019;59(1):289-308. https://doi.org/10.1007/s10943-019-00778-x

36. Mantovani EP, Lucca SR, Neri AL. Associations between meanings of old age and subjective well-being indicated by satisfaction among the elderly. Rev Bras Geriatr Gerontol. 2016;19(2):203-22. https://doi.org/10.1590/1809-98232016019.150041

37. O'brien, B, Shrestha S, Stanley MA, Pargament KI, Cummings J, Kunik ME, et al. Positive and negative religious coping as predictors of distress among minority older adults. Int J Geriatr Psychiatr. 2018;34(1):54-9. https://doi.org/10.1002/gps.4983

38. Veras RP, Oliveira M. Aging in Brazil: the building of a healthcare model. Ciênc Saúde Coletiva. 2018;23(6):1929-36. https://doi. org/10.1590/1413-81232018236.04722018

39. Silva AMM, Mambrini JVM, Peixoto SV, Malta DC, Lima-Costa MF. Use of health services by Brazilian older adults with and without functional limitation. Rev Saúde Pública. 2017;51(1):1-9. https://doi.org/10.1590/S1518-8787.2017051000243

40. Martínez-Reig M, Ruano TF, Sánchez MF, García NA, Rizos LR, Soler PA. [Frailty and long term mortality, disability and hospitalisation in Spanish older adults. The FRADEA Study]. Rev Esp Geriatr Gerontol. 2016;51(5):254-9. https://doi.org/10.1016/j.regg.2016.01.006 Spanish.

41. Chang SF, Lin PL. Frail phenotype and mortality prediction: a systematic review and meta-analysis of prospective cohort studies. Int J Nurs Stud. 2015;52(8):1362-74. https://doi.org/10.1016/j.jjurstu.2015.04.005

42. Fluetti MT, Fhon JRS, Oliveira AP, Chiquito LMO, Marques S. Síndrome da fragilidade em idosos institucionalizados. Rev Bras Geriatr Gerontol. 2018;21(1):60-9. https://doi.org/10.1590/1981-22562018021.170098

43. Messias KLM, Bispo Jr JP, Pegado MFQ, Oliveira LC, Peixoto TG, Sales MAC, et al. The quality of certification of deaths due to external causes in the city of Fortaleza in the State of Ceará, Brazil. Ciênc Saúde Coletiva. 2016;21(4):1255-67. https://doi.org/10.1590/1413-81232015214.07922015 